AsCLEPIO. Revista de Historia de la Medicina y de la Ciencia

66 (1), enero-junio 2014, p030

ISSN-L:0210-4466

http://dx.doi.org/10.3989/asclepio.2014.04

DOSSIER: WAR, EMPIRE, SCIENCE, PROGRESS, HUMANITARIANISM. DEBATE AND PRACTICE WITHIN THE INTERNATIONAL RED CROSS MOVEMENT FROM 1863 TO THE INTERWAR PERIOD

\title{
HUMANITARIAN AID IN PEACETIME: CONFLICTING NARRATIVES IN THE INTERNATIONAL RED CROSS MOVEMENT, 1867-1884
}

\author{
Jon Arrizabalaga \\ IMF-CSIC, Barcelona \\ jonarri@imf.csic.es \\ Guillermo Sánchez-Martínez \\ UPNA, Pamplona \\ guillermo.sanchez@unavarra.es
}

Received: 17 December 2013; Accepted: 20 February 2014

Citation/Cómo citar este artículo: Arrizabalaga, Jon and Sánchez-Martínez, Guillermo (2014), "Humanitarian aid in peacetime: conflicting narratives in the international Red Cross movement, 1867-1884", Asclepio 66 (1): p030, doi: http://dx.doi.org/10.3989/asclepio.2014.04

ABSTRACT: When, scarcely five years after its advent, the movement of aid societies for the relief of soldiers wounded in battle in international wars, set out to examine what should their activities be in peacetime, many debates were opened up as to the feasibility of broadening their field of action to other warlike settings and disasters. The following is an examination of how these debates developed, providing evidence that (a) the International Committee of the Red Cross (ICRC) defended its position not to incorporate civil aims into the humanitarian purposes of the Red Cross international movement until after the First World War; and (b) different national societies and committees of the Red Cross, disagreeing with this position, defended, within the framework of emergent paradigms in hygiene and public health, the care of the sick poor, and were involved as early as the 1870s and 1880s in first-aid to the sick and wounded in everyday life as well as in relief of disasters both natural and caused by famine.

KEY WORDS: disasters; humanitarianism; Red Cross international movement; civil relief.

\section{EL SOCORRO HUMANITARIO EN TIEMPO DE PAZ: DIVERGENCIAS INICIALES EN EL MOVIMIENTO INTERNACIONAL DE LA CRUZ ROJA, 1867-1884}

RESUMEN: Cuando, apenas cinco años después de su puesta en marcha, el movimiento de sociedades de socorro a los soldados heridos en campaña en caso de guerras internacionales se propuso examinar en qué deberían consistir sus actividades en tiempo de paz, se abrieron los debates sobre la posibilidad de ampliar su campo de actuación a otros escenarios y calamidades. Se analiza cómo fueron esos debates, ofreciendo muestras de cómo (a) el Comité Internacional de la Cruz Roja (CICR) defendió no añadir objetivos civiles entre los propósitos humanitarios del movimiento internacional hasta después de la Primera Guerra Mundial; y (b) diferentes sociedades nacionales y comités de la Cruz Roja, discrepando de esa posición, defendieron, en el marco de los paradigmas emergentes en la higiene y la salud pública, la asistencia a pobres enfermos y se implicaron, tan pronto como en las décadas de 1870 y 1880, tanto en la intervención rutinaria en socorro de enfermos y heridos en la vida diaria, como en la atención a catástrofes naturales y producidas por el hombre.

PALABRAS CLAVE: catástrofes; humanitarismo; movimiento internacional de la Cruz Roja; socorro civil.

Copyright: (c) 2014 CSIC. This is an open-access article distributed under the terms of the Creative Commons Attribution-Non Commercial (by-nc) Spain 3.0 License. 


\section{INTRODUCTION}

It was not until after the First World War that the International Committee of the Red Cross (ICRC) agreed to extend its original relief activities -aid to wounded soldiers in international wars- to other causes, related to violent conflict or even beyond them. However, early on, national Red Cross societies had undertaken humanitarian aid in other types of conflict such as insurrections, or civil and colonial wars. Furthermore, despite Hutchinson's claims (Hutchinson, 2000, pp. 8-9), they also proposed that their tasks in peacetime should not only deal with the preparations for war relief, but also be broadened to take in the care of victims of other "calamities" -epidemics, fires, floods, mining or railway disasters, starvation and famine- which threatened the "progress of human welfare".

This article focuses on the earliest debates in the international Red Cross movement about these new areas of intervention in peacetime. The new proposals put forward by its national societies as well as the ICRC's reactions will be analysed, with particular attention to the rationale and meaning of their conflicting narratives, and to the actors involved in them. The high point of these debates was the occasion of the second International Conference of National Aid Societies held in Berlin in 1869 (Boissier 1985, pp. 229-238; Hutchinson, 1996, pp. 92-102). ${ }^{1}$ Moreover, by following the trail of these debates up to the third International Conference of National Aid Societies held in Geneva in 1884, we have detected their eventual convergence with other contemporary debates concerning the search for a general social protection for the systemic victims of modern industrial society, where scientific technology was, paradoxically, the origin of an increasing number of risks and disasters, as well as being an instrument to reduce the former and to prevent the latter.

The first reflections on the convenience of exploring whether aid societies might be involved in the above-mentioned activities in peacetime, came from outside, just after the approval of the Geneva Convention, on the occasion of the third congress of the Association international pour le progrès des sciences sociales (Amsterdam, September 1864). The high interest aroused around the issue led to a specific debate in the next congress of this association (Bern, August-September 1865) within the area of "Welfare and public health". Gustave Moynier and Henry Dunant -both invited to participate in the debate- actively resisted for the first time the suggestion that aid societies for relief of wounded soldiers in campaign might extend their aims in that way (AIPSS, 1864, 7273; AIPSS, 1865, 514-522). ${ }^{2}$

\section{THE SECOND INTERNATIONAL CONFERENCE OF NATIONAL AID SOCIETIES (BERLIN, 1869)}

The earliest formal debates inside the international movement of the Red Cross to define its peacetime activities, took place on the occasion of the second "International Conference of Aid Societies" -the first had been held in Paris in August, 1867-, Berlin 22 to 27 April, 1869. There were one hundred and sixty participants, including the representatives of seventeen governments. It was organised by the Prussian central committee, in accordance with rules laid down by the Geneva Committee. On the eve of the conference, the Gesammt-Organisation der Deutschen Vereine zur Pflege im Felde (General Association of German Societies for Care on the Battlefield) had been constituted as the culmination of a long co-ordination process of different German societies and committees which had begun at Würzburg, in August 1867, after the positive experience of mobilising voluntary civilians on the occasion of the Austro-Prussian war in 1866 (Sudahl, 2001, 79-82; CIACR, 1969, xiii-xiv). The 1869 conference was organised around three major issues, namely the activities of aid societies in a "continental war" (CIACR, 1869, pp. 62-91, 229-234, 247-249), in "war at sea" (CIARC, 1869, pp. 93-118, 234-240, 249251) and "in time of peace" (CIARC, 1869, pp. 27-36, 158-208, 251-253).

When, some months before, in October 1868, the Geneva Committee learned that aid societies' activities in peacetime was planned as one the major issues to be debated in Berlin, their first reaction, apparently led by Gustave Moynier, was to oppose it (Boissier, 1985, pp. 229-230; Pitteloud, 1999, p. 69). Moynier was aware of how much interest had been raised among other international associations with reformist concerns in medicine, public health and welfare, around the potential role of aid societies in peacetime to help populations affected by epidemics, floods, and so on. Yet, he was worried, on the one hand, that these activities would reduce the societies' preparedness to act in case of war; and on the other, that the proliferation of local committees and their eventual drift would mean that the Geneva Committee lost its control of the societies subscribing to the Geneva Convention and their national committees, and that their future would be at risk.

In any case, the Prussian committee pursued its plan to pay major attention to specifying the action of aid societies in the relief of wounded and sick soldiers in peacetime, on the occasion of the Berlin Conference, and prepared a report on the issue with the purpose of articulating the debate and agreements about which activities should be prioritised. The report was accompanied by twenty resolution proposals, the presentation of which was put in the charge 
of Wilhem Brinkmann, ${ }^{3}$ a medical practitioner from Berlin. ${ }^{4}$ The Prussian committee took as a starting point, the fourth resolution of the Conference held at Geneva in October 1863, by which aid societies would always behave in consonance with the motto "in pace para bellum". Thus in peacetime they would devote themselves to developing for the most part, two kinds of activities, namely, the preparation of material aid of every kind, and to train voluntary nurses. ${ }^{5}$ By emphasising the value of their own experience during the Austro-Prussian war (1866), the Prussian committee presented the report simply as a further development of the in pace para bellum principle, even though the ambition of the latter report's principles and aims rather overcame the limits of the former. That was also the perception of the Geneva Committee at its meeting on 10 April 1869 -twelve days before the beginning of the Berlin Conference- in which, having read the report, General Dufour, Maunoir and Moynier himself openly manifested their disapproval (not a word is heard from Louis Appia), although they eventually decided to maintain a diplomatic silence, due largely to the strong patronage of the Berlin central committee by the Queen of Prussia (Pitteloud, 1999, pp. 75-76).

\subsection{The Prussian proposal for peacetime action}

The report began with a hymn of praise to cosmopolitanism as a sign of the times, considering that, beyond differences of opinion and party, there was then a "remarkable tendency to union" aiming to "contribute to the progress of human welfare", which was manifested through the "universal will to alleviate misfortune" wherever it occurred and whatever its causes. After recalling that aid societies' contribution to this task was basically focused on the "help and attendance to wounded and sick soldiers", it went on to emphasise that it was crucial for these societies to reach a "perfect agreement" about their peacetime activities, in spite of the huge variety of proposals being presented. It also stressed that the selection of activities should be guided by a basic principle of human action, namely that efforts and tasks should be oriented towards "feasible and not too remote aim [s]" (CIACR, 1869, pp. 27-28). Besides, it was considered that a close correspondence of aid societies' humanitarian tasks in peacetime with those in wartime was indispensable for making aid societies contribute to another of their basic aims, that is, "spreading knowledge about the laws of humanity to all [social] classes and peoples", and that this would make it easier to set up permanent aid committees throughout each country and would guarantee a general sympathy for their cause. The search for this general sympathy among the citizens - a constant concern in the international movement of the Red
Cross from its very beginnings- was strikingly reiterated during the session as a first and most important condition for ensuring that the population was prepared to voluntarily give aid in wartime (CIACR, 1869, pp. 27-29, 31-32, 170, 173-174).

Finally, no action by aid societies in peacetime should be left to the fate of improvisation or individual enthusiasm without any previous training, and that every action be based on the advancements of modern medical science. While essential conditions for success in their preparatory tasks for war were synthesised as "knowing how to make the best of resources in the area of hospital administration, hygiene and service", the success of their actions in peacetime was described as being dependent upon the concurrence of three pairs of conditions, namely, science and work, reflection and activity, intelligence and experience (CIACR, 1869, p. 158). The true purpose of the Prussian committee was demonstrated by the fact that only the last third of its report was devoted to preparatory tasks for war, while the limits of the traditional principle in pace para bellum were totally overshadowed in its two first thirds.

\section{Peacetime activities for preparing war relief}

Three demands were particularly emphasised, namely, to use the experience gained in recent wars, to spread, through different means, the measures to be taken in wartime; to keep in contact with the military administration in order to grant a basis as solid as possible to aid societies' efforts; and to have a "complete and detailed plan" for material help (CIARC, 1869, pp. 32-35).

Particular attention was paid to the establishment of reserve hospitals in case of war, in those "cities favourably placed" that the corresponding military authorities had previously designated for this purpose. The efforts of the aid societies at this point should be addressed to choosing the most suitable emplacements as much as to preparing their organisation and direction, and to committing the personnel-physicians and nurses- prepared to voluntarily work at them. The importance of lazarettos was underlined, those establishments ready for use, where infectious patients could be isolated in case of epidemics. There, "salubrious conditions for patients' isolation" should be provided by means of a prompt application of "all the essential improvements of hygiene", in order to stop the spread of epidemics. This also applied to barracks and tents whose utility for treating serious wounds and contagious diseases had been already proved. ${ }^{6}$

These preparations should allow the aid societies not only to provide "the military authorities with a regular administration of hospitals in wartime", but also that a "well organised corps of first aid" made up 
of "active and vigorous men" who had been conscientiously chosen, could give help under the most strict discipline in the theatre of war and on the battlefield by counting on the "first aid and rescue devices". The activity of these men should be extended to the transportation of wounded and sick soldiers, and to their transfer at railways stations. It was considered as essential that these teams were convened and trained in peacetime according to specific circumstances in such a way as to qualify them to accomplish their tasks in wartime.

\section{Peacetime action beyond war relief}

For the Prussian committee, the "works of humanity" of aid societies in peacetime should be focused on taking care of the sick poor, and on helping people on the occasion of "public calamities", since both activities would result in benefits for war relief: the former would make it possible for a wide contingent of voluntary health care personnel to be trained, while one outstanding advantage of the latter was that it instructed the provision of a "prompt and organised aid" (CIACR Berlin, 1869, p. 29). Yet, the Prussian defence of both aims and the subsequent debate on them, went on to converge with contemporary reformist social concerns caused by the serious deterioration in the life and health conditions of the working class and others then living in the overcrowded suburbs of those European cities that were then the scene of the industrial revolution. ${ }^{7}$

\section{Furthering professional nursing to care of the sick poor}

Brinkmann particularly stressed the feasibility of "perfecting and improving all the aid organisations of the sick poor". If, up to then, the supply of material aid had had to be very selective due to the "actual impossibility of choosing and training, after the outbreak of a war, any suitable hospital personnel", he considered that it was right for the aid societies to take responsibility in peacetime for reinforcing their civilian health care resources by increasing their forces and improving their training (CIACR, 1869, pp. 29, 156). For this purpose, they counted on religious personnel of both sexes (Sisters of Charity, Deaconesses and their male counterparts) whose vocation led them to look after the patients, and that, due to their training and religious vocation, were "the ideal of male and female nurses", and possessed "indispensable qualities for being carers of sick people". 8

Yet, as the Prussian central committee did not hide the fact that it preferred the practice of these functions not to be subject to a "vote of piety", Brinkmann proposed that nurses be trained by the initiative of the aid societies as a way to better face the new challenges. After describing the positive experience-de- spite their lack of training and practice- of the mobilisation of "women and young women" of every social class, who had voluntarily thrown themselves into the care of patients during the recent Austro-Prussian war (1866), he defended opening up the field of work to all women, arguing not only that it perfectly fitted "their aptitudes of heart and spirit, their forces, and their inclinations", but also that it would allow a great number of women to escape from "an existence lacking of joy and satisfactions", and introduce them "into a sphere of action suitable for educating their heart and intelligence". And further to acknowledging nurses' elevated place in the universal esteem, he asked for "full protection and complete security" for the new female profession.

This proposal was justified by reasons of convenience as much as the certainty that the care of patients was a line of priority action "in the universal task of the humanity and love for fellow people". In this task women should play a key role, by virtue of not only the alleged constitutional condition of female religiosity and piety, but also of the fact that up to now, the "valuable talents" of those women of "most distinguished education" bearing "in their hearts the most profound feelings of religion and morality" and being "full of devotion for humankind" could only have been used in wartime and in an imperfect way as a result of their lack of training. The Prussian committee accepted the training of professional nurses -a challenge that had great social prestige among "distinguished women and men"-, and emphasised that its implementation demanded from aid societies the capacity to offer women guarantees similar to those of the houses managed by the Sisters of Charity and Deaconesses, as much as to "employ the energies of these caregivers and ensure their morality and ability" to regularly perform the care of the sick poor. ${ }^{9}$

It was also proposed that aid societies gave the requested experience as voluntary nurses to those women who, although unable to devote themselves professionally to the care of patients, would like to help their fellow man by looking after the sick poor "in time of exceptional misfortune, in time of war and of epidemic", and it was believed that this would counter the dangerous error concerning the care of patients, of "believing that enthusiasm in itself can bring about great things" (CIACR, 1869, p. 157). In contrast, the training of male nurses was emphatically ruled out for hospital service on the assumption that, even though they were "necessary in the major hospitals in peacetime and indispensable in wartime", their training unavoidably required "a severe discipline and a military instruction" that only the State could guarantee. ${ }^{10}$

\section{Providing relief in public disasters}

Regarding assistance in public disasters -among which epidemics, floods, fires, railway and mining dis- 
asters, starvation and famine were enumerated- the Prussian committee's report proposed that aid societies should fight with the same means and the same energy against the destructive forces -calamities and other exceptional circumstances- in war as in peace, claiming that charitable efforts in both, fed back on each other. Resting on the assumption that each action of dedication contributed to the spreading of the "laws of humanity" throughout the world, they claimed that only in this way would it be possible to accomplish their mission "to spread everywhere the charitable thought on which the Geneva Convention was based, and to guarantee its public approval, so that it entered people's hearts and sowed its seeds for the future" (CIACR, 1869, pp. 31-32).

In his interventions as the Prussian speaker, Brinkmann stood up for the establishment of a school in peacetime to train "exercised and well-tried forces" to perform voluntary aid action during war; and he reiterated that the best training for this purpose consisted of fighting against analogous circumstances to those of war, namely, disease, destitution, hunger and the "devastating force of the elements". To him, all these voluntary aid activities would secure the mission of the societies under the Geneva Convention "by means of the exhilarating example of action, by means of that love of humankind that surely continues to be felt amidst the all too numerous calamities of peacetime" (CIACR, 1869, pp. 154-155).

Brinkmann justified this way of acting by the existence of a single "law of charity" the implementation of which to distinct "faces of human misfortune" required the combination of the most diverse efforts, forces, means and institutions. However, in order to make an exercise of charity to be truly beneficial he considered that it should have a clearly scientific basis on "precise knowledge, training and special studies", and a methodical implementation, avoiding random interventions encouraged by vague sentimentality or "being moved simply by the heart" (CIACR, 1869, p. 155).

Attention to "the misfortunes of poverty and disease at the bedsides of helpless people" would also offer the advantage of exercising "pure charity and the spirit of sacrifice" without the disturbing influence of the aggravations of war. So, aid committees' preventive efforts in the middle of the "terror caused by pestilential and contagious diseases" would be a valuable training for hospital service in peace as much as in war. Furthermore, "sudden disasters, so numerous as a result of the tempestuous agitations of our time" would allow the identification of those "men of heart and action" called to perform the role of "rescuers" in the battlefields (ClACR, 1869, pp. 155-156).

\subsection{Maximilian Schmidt's views: broadening relief activities in peacetime}

After two shorter speeches by delegates of the French and Hessian committees that will be referred to further on (CIACR, 1869, pp. 159-163), Maximilian Schmidt was asked to speak. The session President authorised the intervention of this medical officer of the Prussian army who had actively participated in the previous general meeting of the Prussian central committee, even though he was not properly delegated to the Berlin Conference, in acknowledgement of his "great knowledge about the question and his long experience". ${ }^{11}$ His exposition, doubling in length that of the Prussian representative Brinkmann, had two, clearly differentiated parts. Schmidt first confined himself to three practical aspects of the Prussian proposal, which he had developed and for which he had done his best to provide a theoretical basis at the same time focusing on what he defined as "the philanthropic concerns of our time" that he considered to be related to the Prussian action plan for peacetime.

Schmidt highlighted the nobility of the proposed new tasks, qualifying them as an "important link in the chain of works of great love to humankind" that the international association of aid societies should develop along with the preparations for war "in all the great, civilised states of the present times". To him, with these tasks, this international association established on the basis of the Geneva Convention, would enter a new and extremely important stage of its development, in which temporary utility would be replaced by a "complex aim" and "a permanent utility". Moreover, these activities would be the best guarantee that aid societies could enjoy a lasting influence and maintain the benefits of a "national sympathy" that -he reminded the delegates- was subjected, like any other human endeavour, to "general laws based on the nature of things of men" and, therefore, always in direct relation to "the closeness or distance of its object and its utility". To Schmidt, in short, if it could count on the "willpower" of the international association and the support of the "public spirit", the Berlin Conference would pass "into the history of aid societies in the same way as Geneva on the day the Convention was approved" because of the relevance of its resolutions (CIACR, 1869, pp. 173, 164, 173-174, 170-171).

\section{Proposals of humanitarian action for peacetime, and social "organicism"}

Schmidt formulated three practical and versatile proposals:

1) To create a transportable barrack-hospital system that in case of war would relieve overcrowding in military hospitals, and to establish "systems of pavilions", while in peacetime, installed in conven- 
ient places, they would be useful in facing extraordinary calamities (epidemics, fires, floods, and so on) and in rural areas even in ordinary circumstances (CIACR, 1869, pp. 164-165).

2) To establish "reserve ambulances" consisting of "houses of convalescence" to be erected in capitals and big provincial cities, that might be used for attending in peacetime to the demands of the population, living in overcrowded conditions as a result of the development of modern industry allegedly, "one of the glories and, at the same time, one of the great dangers of our century". These houses of convalescence could also be transformed into reserve hospitals in case of war. ${ }^{12}$

3) To distribute voluntary tasks among the members of the aid societies in peacetime in such a way that the "care of sick people" would be assigned to women's committees while the "organisation in support of public hygiene", to the men's (CIACR, 1869, p. 166).

The theoretical bases of Schmidt's proposals were indebted to an organicism that was very influential in European social science at the time. To him, the "physical perfection of the nation and, therefore, of its army" depended -irrespective of the geographical position of a country or of the nature of its land - upon the "general life conditions" of its population (namely, air, water, food, clothing, housing, personal care and hygiene, and work); thus the integrity of that set of "primary conditions of physical life" was the main determinant of "the health and strength of a nation". Moreover, Schmidt maintained that there was an absolute mutual dependence among all social classes, so that when a member of the social body suffered, all the rest suffered with it. From this perspective, disease and mortality among "the inferior classes" greatly determined those of the "superior and middle social spheres", so that the better off were "continuously exposed to the same dangers as the poor classes" despite their relatively superior living conditions (CIACR, 1869, pp. 166-167).

From his Arcadian view of an ancient civilisation whose fall had for centuries had serious consequences for the "European race" because of the lack of a wide-ranging, reliable and state-organised hygiene, Schmidt saw as a sign of the return to "more healthy visions of the conditions of public prosperity" that modern natural science was promoting "a movement towards re-establishing the importance of public hygiene" and as an example of this he spoke of the institutionalisation process of public health in England led by John Simon (1816-1904) and the public attention it had attracted over the past ten years. ${ }^{13}$
Without denying that in Germany there was in fact a theoretical interest in the legal development of public hygiene, he requested the introduction of radical remedies -by multiplying "official preventive measures"instead of only palliative ones -increasing the number of hospitals - in the face of such a crucial public health issue as the increasing overcrowding of the sick poor in German hospitals. And more generally speaking, he claimed that the state should take, by right and duty, the initiative in all public hygiene matters, on the assumption that it was an issue of public and incontestable interest, and that the health, strength, and life of a nation was actually at stake. ${ }^{14}$

On the basis of this, Schmidt suggested that the Prussian aid society may be the "perfect organ" to solve the serious public health problem derived from hospital overcrowding of the sick poor, by virtue of its hierarchical organisation and interconnection, both internal and with the official administrations. To him this aid society counted, in the major cities, on a number of voluntary workers large enough to undertake such an "endeavour of public utility concerning the common good" and, at the same time, this activity would contribute to its social reinforcement. Moreover, reflecting on the Prussian aid society's patriotic agenda, he remarked that there was no better leverage aid committees could activate in peacetime than this, in order to "increase public prosperity and national power". Thus, Schmidt closed this part of his speech by recalling that the proposals of well understood public hygiene made by the Prussian committee concerning the care of the poor would also increase, particularly in the industrial areas, the "availability" of "the poor classes" for work and military service (CIACR, 1869, pp. 166, 168-169).

\section{The "philanthropic concerns of our time"}

Schmidt placed (CIACR, 1869, pp. 169, 173) the aid societies' philanthropic concerns in a time of "transformation" in all the orders of social life and of "intellectual and moral development", allegedly characterised by an active and general sympathy for all the endeavours whose purpose was the public good and, in a show of somewhat exaggerated optimism, he claimed that "in our days, every really useful and well-expressed thought, [could] rely on the voluntary collaboration of all the forces needed for its implementation".

Among the "most precious and important" results of this alleged civilising development, there was an "increasingly visible approach between the rich and middle classes, on the one side, and the inferior classes on the other" as well as a "pronounced tendency to establish warm relationships in the most extreme conditions, under the influence of the true 
charity that reminds men of the beneficial principle of equality". Schmidt drew a parallel of the abolition of slavery in the USA and of serfdom in Russia, with a movement -allegedly increasing in Europe- in favour of suppressing extreme poverty -pauperism-, and pointed to the need to destroy this internal enemy, so dangerous as "unworthy of civilisation", and which he perceived as a constant threat to social prosperity, with its "sinister entourage of hunger, destitution, disease, ignorance, and bitterness". After noting that in Europe there were numerous associations devoted to "relieving the major misfortunes of sick and poor people unable to earn a living", and operating from the most disparate perspectives with no previous agreement or any unity of action, Schmidt proposed the adoption of a peace programme working on the perspective of an aid organisation that accompanied "as much as was necessary, the poor and destitute from their birth, throughout all the stages of their lives, under every form of suffering ..., until the return of their remains to the earth". To him aid societies should contribute to the achievement of this ambitious aim by three means, namely, by showing their sympathy for the always pressing needs, by establishing mobile hospitals and houses of convalescence to care for them, and by improving the public health to the benefit, mostly, of the "inferior classes".

In his effort to prove that these tasks did not in any way distract the aid societies from their essential aim, Schmidt emphasised the usefulness of exchanging experiences between civil and military health services as a way of boosting innovations in health care, by resorting, once again, to the Anglo-American reformist image, this time the outstanding studies on hospital hygiene by James Young Simpson (1811-1870) in Edinburgh, and William Alexander Hammond (1828-1900) during the long American civil war, as well as to diverse novel hospital experiences in Rome and Paris. Through these, he was able to point out the proven decrease in the highest mortality and morbidity rates of infectious diseases that were so common in great old hospitals, as a result of changes recently introduced in hospital architecture -e.g., replacement of stone by iron and other materials lightening the buildings and making them "more aerial"- as well as in the management of hospital inmates -separation of sick and convalescent patients in different pavilions, and continuous evacuation of the latter from the major hospitals. ${ }^{15}$

\subsection{Alternative views and proposals on humanita- rian action in peacetime: debate and conclusions}

The solid coherence of the report elaborated by the Prussian committee plus the determined gloss added by Schmidt, caused the debate to develop as an ebb and flow of resistance. On the one side, the will of the
Prussian representatives was that all national societies supported the report as a whole, and wanted it to be broken down as little as possible, because it perfectly fitted the specific model of aid societies adopted in Prussia, where they meshed perfectly with the machinery of the Prussian state. On the other side, there were other speakers who were less in favour of such strictly prefigured scopes for action, and proposed other options to be implemented in contexts with very different socio-political models. This fruitless debate around an unmoveable block meant that at the close of the conference, neither sides' resolutions on action in peacetime had been approved in their entirety, so that the spirit of the whole was maintained as before; that, in general terms, aid societies would keep within the bounds of service to the armies and only occasionally act on their own. Actually, the Prussian proposals approved almost word for word by the assembly were the most programmatic ones, those postulating the aid societies' priority attention in peacetime to the care of the sick poor and to giving rapid and organized help to the victims of public disasters, by stressing the particular usefulness of such help in order to achieve a "vigorous development" of these societies. ${ }^{16}$

There were three issues, however, that opened a way through the impasse by producing an open debate. Although they did not result in any specific programmatic resolutions, they did actually fix the limits of Prussian ambition. They also permit us to characterise the range of sensibilities and the concerns of different aid societies by showing rather more diverse perspectives on what should be the nature of these societies. These issues dealt with management -the request for more autonomy for local committees to organise their activities-, with a perspective more social than administrative -the prioritisation of activities to promote public hygiene-, and along with the control of the aid societies' own efficiency -the need for the aid societies to also take charge of training male nurses.

\section{Claiming more autonomy for local committees to or- ganize their own activities}

With regard to the management model, a great many of the delegates, including those of other German states, considered that the Prussian committee's proposals were excessively centralist, and restricted the autonomy of action that national and local committees demanded for themselves. The intention of the Conference secretary himself -the Regency Counsellor Hass- to support Brinkmann's speech, by emphasising the importance of the aid committees' activities in peacetime covering "a field as wide as possible" -which implied not only taking advantage of them as valuable resources not be duplicated in other 
administrative spheres, but also sanctioning the new roles and functions assigned to them from outsideonly served to increase the other committees' susceptibilities (CIACR, 1869, p. 161).

Very illustrative in this respect was the speech given by Léonce de Cazenove, lawyer, active member of the central committee of the French aid society, and secretary of the local committee of Lyon, who that year would publish a monograph mostly to reflect the organisation and activities of "the work" (l'oeuvre) in France. De Cazenove was reluctant to excessively diversify the activities in peacetime for he considered that it would lessen the resources available in case of concurrent land or sea war, and he was in favour of aid societies, in the face of major disasters, restricting their help to a moderate economic contribution from either their general account or their reserve deposits for contingencies other than war. However, he proposed concentrating their energies -always in a moderate way- on relief to the "victims of accidents" and on other activities both logistic and propagandistic, as contemplated in other Prussian proposals (CIACR, 1869, pp. 159-161).

The intervention of the two delegates from Hesse -one of the German States then still resisting the pretentions of Prussian supremacy-, ran along similar lines. They were two members of Hessian court of appelation, namely the lawyer Büchner and the advisor Weber. In fact, this committee had sent to the Conference a resolution proposal in which the local committees were given autonomy to develop their "own activity regarding the administration and use of the resources" except for the part of their dues that contributed to the central committee's account in each country. So, without denying the need for the different aid societies to keep themselves active in peacetime and preserve their unity of action, Büchner opposed the excess of "centralisation", claiming that local committees enjoyed a certain freedom in their movements and objects of action at that time. And Weber went even further in claiming that local committees' autonomy of action should be extended in a general sense, i.e., that it be applicable "in periods of peace as much as in circumstances of war". In the face of this resistance, the Prussian representative, Brinkmann, adopted the position of making concessions but maintaining the limits. For instance, he proposed giving the local committees greater independence in their peacetime action within their relevant spheres, albeit respecting their subordination to a particular centre that would not impose "a rigid and inflexible centralisation" -which would allow no central committees even to "act on their own in multitude of essential things" in wartime. These concessions did not please Weber who responded by recalling that the recently signed agreement on a general organisation of the German committees had assigned the central direction in case of war, an influence "purely consultative as regards indicating extant needs", and highlighted the difference between the army's functions and those of the committees' central direction. Thus he insisted on keeping as much as possible the freedom of action of the committees of relief.

The interventions of the committees' delegates from Catholic Bavaria and Austria, and Russia, also revealed anxiety in the face of the overwhelming agenda of the Prussian central committee. For instance, Dr. Held, representative of the Bavarian central committee, having emphasised the convenience of always distinguishing between possibility and opportunity, suggested re-writing the Prussian proposal. He proposed moderating its tone by diluting its aims as well as its idea of unity of action, in order to avoid the misunderstanding that it aimed to impose an exaggerated centralisation on the committees' agenda in peacetime (CIACR, 1869, pp. 175-177). For his part, the Baron Von Krauss, of the Austrian committees -in plural-, warned of the difficulties that could emerge in different countries to fully implement the Prussian committee's proposals and, anticipating a foreseeable refusal to accept this centralisation, defended the idea of leaving it to the discretion of each State whether to execute or not such proposals "depending on time and circumstances". To support his views, Krauss stressed three features specific to the diverse and varied Austrian aid societies, that did not fit into the model of the Prussian proposal, namely their close links with the chivalric orders - that of St. John of Jerusalem and the Teutonic- and other religious associations devoted to analogous tasks; their developing activities of "relief to soldiers whose wounds had led them to indigence as well as their families"; and the imminent creation of a "body of porters (Transport Corps)" for health care equipment. ${ }^{17}$

The representative of the Russian committee, the physician and state counsellor De Hubbenet -most probably Anton Christian August von Hübbenet (18221873), professor of surgical clinics in the University of Kiev and at some point Chief Physician of the Russian Army-, ${ }^{18}$ chose to express his concern that the Prussian proposals could -because circumstances were not mature enough-disrupt or even subvert the viewpoint of the Geneva Conference, and that the committees, unable as they felt to undertake such new tasks with success, were heading for total failure. After having remarked that in Russia there were many aid societies and women's committees specifically devoted to the care of sick and poor people, and noting that it was usual in the case of disasters to organise initiatives, either governmental or private, voluntary committees to provide relief to the victims, he considered that opening up these activities to the Red Cross would 
do little to reduce their sufferings, but might seriously damage its mission. He also pointed out that using the money and goods collected by the Red Cross societies for other purposes would stir up a general manifestation of disapproval because they had been donated for a specific purpose, were a "national property" and, as such, were "sacred". Furthermore, if destiny brought a lasting peace among nations, it would cease to be justified from the viewpoint of philanthropy and political economy to divert large amounts of donated money to wartime needs (CIACR, 1869, pp. 180-181).

Similar caution was shown by another French delegate, the Count of Beaufort (Beaufort 1870, 1875), who, despite agreeing that the spirit of charity in peacetime did not stop with good words but was translated into acts, did not find it acceptable to prearrange in general terms the charity activities that all aid societies should implement, for "the circumstances, the precedents, and the customs" conditioning these interventions could be highly variable. Among them he emphasised the importance of those actions that encouraged beneficence, whenever they were based on specialised works and studies aiming to coordinate the efforts and to improve the means of action. He recalled his vote at the previous Paris Conference of 1867 in support of aid societies in peacetime attending to crippled soldiers, as well as the Association pour l'assistance aux mutilés pauvres which he had founded for that purpose with the help of other outstanding members of the French committee. Furthermore, by imposing an annual fee of one franc, the Count of Beaufort proposed to avoid the problems mentioned by Von Hübbenet, by recommending that nations establish two societies in parallel, each with its own aims and budget, but both of them under the same direction and made up of the same members: one would be devoted to relieving the sufferings of war, the other, "the sufferings and misfortune of those workers whom accidents had prevented from earning a living". These two societies that would give support to each other and be funded from a single fee, would permit the maintenance of the "vitality of the aid societies in time of a lasting peace". ${ }^{19}$

Faced with so much opposition, the Prussian delegate took a step back in order to smooth ruffled feathers, arguing that the sphere of aid societies' activities in peacetime could not be "subjected to international resolutions", so that the Prussian committee was pleased to accept that the action of the different committees in peacetime was related to the circumstances of the country and, at the same time, subject to the way those committees organized their action in wartime. In practice, it merely implied that the exportation of the Prussian model was not recommended, although this model remained protected and recognized by the international conference -a feature that was in the practical interest of the Prussian committee with regards to its relationships with the remaining committees of the German confederation (CIACR, 1869, p. 190). The approach took place thanks to the intervention of the influential professor of pathological anatomy at Berlin University and member of the large Prussian delegation, Rudolf Virchow (18211902) ${ }^{20}$ who enabled the different positions to move closer and to end the debate with an agreed proposal that modified the original one. By arguing that its German writing seemed to claim "rigorous and almost military measures with regard to the centralisation" that Virchow by no means considered appropriate- he declared himself in favour of giving more autonomy to the local committees in order to avoid their excessive dependence on a central authority, ${ }^{21}$ and manifested his sympathy for the claims to give the local committees "the freedom to assign themselves the different tasks in their activities according to their particular aptitudes and circumstances". At this point he praised the assistant committees' experiences in the care of the "valid soldiers" (militaires valides) -as opposed to the "invalid"- on the occasion of the Austro-Prussian war of 1866, and finally, the "solid and close union of all the aid societies of the country that formed a very compact whole". Thus the initial proposal passed from being protected as an "essential condition for their efficiency during war and during peace" to be postulated rather as something that should "be sought for the sake of efficiency" (CR-CIARC 1869, pp. 16, 198).

\section{Promoting public hygiene}

Schmidt had already made some general references to the aim of placing the aid societies' activities in the sphere of public hygiene, but two responses to the Prussian official report presented by Brinkmann went beyond that, arguing why it should be so and how it should be carried out. They were that of Virchow, and the response of the Hessian delegation in defence of their resolution proposal on the issue.

Virchow started to address the public hygiene issue by asking rhetorically why the key question in most discussions was to what extent the aid committees could be forced to fill the gaps left by the military health services in wartime. Embarking on a series of reflections in which he set out to criticise the view that subordinated the aid societies' activities in peacetime to the perspective of war, he wondered at the value of that forced connection -as if "war were in Europe the natural state" and "peace only existed to prepare ourselves for war". He asked himself whether the many activities and devoted and trained people whose natural place was in civil life, should be subjected and subordinated to the needs of wartime. ${ }^{22}$ Continuing in this self-questioning mode -most probably trying to 
avoid the perception that he was actually questioning the official Prussian line, Virchow also wondered whether it was sufficient that aid committees were organised only for the purpose of war, or that an "organisation of peace" should be established alongside them in order to assert the aid societies' definitive, formal, and unreserved commitment to work "in the perspective of peace". He claimed that "civil society" (Société civile) had not found even then -twenty years after the failed liberal revolution of 1848 , in which he had been so actively involved in Berlin- ${ }^{23}$ any satisfactory answer to their urgent demands in the "official organs" of the State, the municipalities, or even the Prussian voluntary committees. He was also in favour of expanding the organisation of aid committees by setting up, as a kind of "special subdivision", a "parallel category of peace committees" whose action would be focused on the care of the sick and public hygiene, in line -he recalled- with the proposal the Conference had received from the Hessian committee. Only in this way, by not "considering war as the main aim of our committees' action" would it be possible for the question of the creation of the required personnel of male nurses to be dealt with without falling into a vicious circle.

However, although arguing that the aid committees should first develop pilot projects to provide practical examples in that area, and recognising the great difficulties involved in obtaining the needed support of the population, Virchow refrained from making any specific proposal on the issue. Yet, he suggested that a new conference of aid societies should undertake as its main task discussion on the "means of breaking the narrow circle exclusively restricting our work to the case of war", in order to ensure that the care of the sick in ordinary times was not a mere "means of education within the perspective of war", but an "end sufficiently considerable in itself as to legally demand everybody's attention" (CIACR, 1869, pp. 185-187). ${ }^{24}$

On their side, the delegates from Hesse were insistent that the action in peacetime should be toward the sphere of hygiene, on the assumption that the aid societies' organisation and activity should be "directly and effectively practical in peacetime". Thus, they proposed that public hygiene be favoured through scientific works -with a specific emphasis on statistical studies and, again, on British sanitary science- and activities contributing to its theoretical diffusion and its practical application, above all in barracks, hospitals, prisons and schools (CIACR, 1869, pp. 46, 206). Two of the Hessian delegates, first Buchner and then Weber, diligently defended the proposal. Buchner maintained that in peacetime aid societies should focus not only on preparing themselves for war, but also on the greater ambition of contributing to the achievement of a "universal hygiene" (hygiène universelle), as was set out in their resolution proposal. He illustrated it by drawing a parallel between the aid societies' tasks and those of fire-fighters who, in addition to putting out fires, developed "other tasks albeit always in the neighbourhood of their post" (CIACR, 1869, pp. 161163). The following day, Weber again took up the defence of the Hessian committee's proposal, using Virchow's authority as a protective shield. He claimed that the final object of aid committees was the same in wartime as in peacetime so that, far from it being necessary to seek "alien occupations" for them in peacetime, it might be assumed that "preserving human lives in circumstances in which a great number were at the same time, at great risk", was the most generic, shared object for both times. The aid societies' task should not just be "sustaining the war, but warding off the evils" that could happen in war as well as in peace. Thus, although the single object of aid societies in the beginning had been to re-establish the health of wounded and sick soldiers, it was now time to face prophylaxis -the "preventive measures" against everything that might damage health. To support this claim he referred to the dramatic results obtained by Florence Nightingale in the care of wounded and sick soldiers in war hospitals in the Crimea, and to the proven experience that in wartime the number of victims from enemy bullets was much lower than that of victims from diseases. And again he demanded -as his compatriot Buchner had previously done- that aid committees in peacetime should make their priority attention to the "science of hygiene as a whole" on the basis of the immense importance that it had "for the fortunes of our poor, of the industrial workers, of the soldiers, of the prisoners, of the schoolchildren of our own children who so great promises represent for the future". 25

Trying to redirect the debate, Brinkmann centred his answer to both Virchow and the Count of Beaufort -the French delegate- on reiterating the official Prussian position, which was to consider, for the moment, the "needs of peacetime only as a school for the needs of war", with the hope that someday "in a distant future", war relief would be nothing more than a "reflection of the general activity of humankind" (ClACR, 1869, pp. 190-191). Thus, it was necessary to fix some limits to the action of aid societies in peacetime; namely "they will be a school for what we will have to do during war; they cannot, therefore, be a matter for just any universal activity or humanitarian association". ${ }^{26}$ And although he finally declared that he supported the need to orientate this action to the sphere of hygiene, as presented by Weber, scarcely a tiny minority of delegates were finally able to endorse the Hessian committee's proposal (CIACR 1869, p. 207). 


\section{Should aid societies also train male nurses?}

The debates went back and forth and various discrepancies eventually meant that the discussion about training nurses turned into one specifically about the training of male nurses. The official Prussian committee hoped that this debate would quickly skim the surface, and stressed the need for male nurses to become accustomed to operating as a disciplined body in order to achieve that spirit -linked to military instruction- that only the State could offer. However, underneath there was another debate going on about seeking other qualifications on the assumption that the aims were also different.

The official position considered any involvement of aid societies in training male nurses as inappropriate "in the present circumstances" by virtue of the nature and aims of these societies, and was assessed by Virchow -this time without caution!- as narrow-minded. Far from underestimating the indispensable role of women in this task in wartime, Virchow defended the need for aid committees to also be in charge of the education of male personnel in order to avoid leaving it exclusively in the hands of the military administration, on the assumption that male nurses were the indispensable element for the reserve ambulances $-a$ service that was one of the main tasks of the aid committees because of its work in picking up the wounded and sick removed from the battlefield and to prevent contagion of diseases on a larger scale. Moreover, in this way the aid committees would also have the chance to choose a more qualified personnel than that available among the military bodies in campaign (CIACR, 1869, pp. 187-188).

Virchow's speech was followed by the sculptor and member of the Berliner local committee Alexander Gilli (1823-1880) ${ }^{27}$ defending the idea that both tasks be undertaken; namely, guaranteeing women's right to become nurses in peace as in war, and the training of male nurses to enable them to use first-aid resources on the assumption that "the battalions and the great organisations established by the State" were not sufficient "to help the wounded in the battles where peoples' destiny [was] decided". However, to Gilli, male nurses specifically trained for hospital work -as understood by Brinkmann- were useless for the latter task. Since it was required to be instructed in the use of the various first-aid material stored by the relevant aid committee, he claimed that it was more adequate to found -and train- in peacetime a "urban health care guard" (garde sanitaire urbaine) that could attend to sudden health demands -a health care guard similar to the "relief to the wounded" (secours aux blessés) already existing in different French cities. In this way, he was proposing that aid societies for relief of wounded soldiers took over the project that another member of the Berliner committee, Dr. Julius Beer $(1822-1874),{ }^{28}$ had been fruitlessly demanding for years from the municipal authorities of the Prussian capital, namely, that a "type of security night guard" was created in order to resolve the frequent difficulty of providing, in the increasingly populous cities and particularly at night, prompt medical first aid to those having suddenly suffered health problems or accidents on the streets. He specified that the required personnel for this guard could be found among the "body of health care assistants (Heilgehülfen)", that these people were totally trained and could be freely put at their disposal. Brinkman did not oppose this initiative but he tried to avoid it by turning to the issue of the requested qualification level, arguing that the debate was not about "training male nurses but simple nursing auxiliaries". Neither general Von Baumgarten -the representative of the Russian Empire's War Office- nor the pastor Hahn -the president of Wurttemberg's central committee- agreed with this: the former because some local committees in Russia were already training male nursing auxiliaries with a higher qualification in order to help "our male military nurses", while the latter disagreed because the Wurttemberg committee was already training male nurses in a new, recently founded establishment, and even receiving military permission for the trainees to "participate in the exercises of the sanitary companies at the same level as soldiers".

Thus, in contrast to what had happened with the earlier attempt to place aid societies' activities in the wider context of improving public hygiene, in this case the generalised refusal forced the Prussian committee to withdraw their proposal that young men should be excluded from the aid societies' training programs for nurses (CIACR, 1869, p. 201). Although no further decision was taken about how to implement male nurse training, the general idea was not put completely out of court.

Yet, there was one last debate on the issue when the assembly went on to discuss another proposal of the Prussian committee, suggesting that a "health care corps" (corps sanitaire) made up of "active and vigorous men" should be selected and equipped as a useful instrument for the relief companies. When the issue was first presented, the delegate from Hesse, Weber, retrieved an earlier Hessian proposal in favour of creating "voluntary bodies of health carers" from the gymnastics societies (Sociétés de gymnastique), and of giving them a theoretical and practical training. He based the proposal on the good functioning of the "company of male nurses and porters, selected among the gymnasts" that had voluntarily offered itself to serve on the occasion of the Austro-Prussian 
war (1866), and noted that since 1867 its members had been receiving at Hesse theoretical and practical instruction "under the direction of civil and military physicians" (CIACR, 1869, pp. 202-203).

\section{NEW ACTIVITIES FOR PEACETIME}

Perhaps having a premonition of what was about to fall apart -hardly fifteen months later the FrancoPrussian War broke out- De Cazenove concluded his speech with an emotive encomium to what he claimed to be another major aim of the Berlin Conference, namely, "a moral proximity among peoples" thanks to great progress in different means of communication:

Being in daily communication through the electric telegraph, the railways, the sciences and the arts, showing themselves more accessible to each other through the study of languages that is now an important part of the education of the next generation, people may enter, so to speak, into each other's hearts, establish a kind of communal solidarity, and form a vast network, so interconnected that it cannot henceforth be easily broken (CIACR, 1869, p. 160).

In fact, the Franco-Prussian war (1870-1871) abruptly terminated the debate on whether aid societies' peacetime activities should be opened up to new objectives, or rather restrict themselves to the relief of invalid soldiers. The resumption of the debate after the war was greatly conditioned by its aftermath as well as by the new actors and priorities in civilian health policies.

Prussia's military victory was so overwhelming that the Prussian army became in Europe, the pattern for organising armies and recruiting their soldiers (conscription system) as well as for regulating the functioning of relief societies for wounded soldiers. This model stressed the subordination of the aid societies to military commanders. During the war there were innumerable ambulances on the battlefield either managed by the national aid societies of the contenders -very efficient on the Prussian side, and rather chaotic on the French- or foreign aid services, mostly coming from England, Ireland, the Netherlands and Belgium. These tended to act apart from the national societies and armies of both contenders, sometimes even being protected by the national societies of third countries, and always felt themselves to be legitimate in undertaking their relief action in an autonomous way. The war experience had raised many criticisms by the commanders of the European armies and of their military health services, like those of Thomas Longmore, responsible for British military health services, and even by the Prussian national aid society itself (Longmore, 1872). Thus at the Congrès international sur le service médical des armées en campagne held under the auspices of the 1878 Paris Universal Exhibition, it was agreed that access to the battlefield should be only permitted to military health services and, following Prussian demands, that ambulances of any relief society -even the national ones- were forbidden to gain access, arguing that these interventions had been neither approved by the governments signatory to the Geneva Convention nor referred to in any way at all in that agreement.

The resumed debate on humanitarian action in peacetime during the 1870 s, was very much within a new framework of new public health views and practices dominant in Europe at the time. Significantly, after a failed international conference of aid societies to be held in Vienna in 1873, the Red Cross societies met again with a much lower profile in Brussels in 1876, on the occasion of a wider conference -the $1^{\text {st }}$ Congrès international d'hygiène, de sauvetage et d'économie sociale. Its three major areas -hygiene, rescue and social economy- were intended to gather together discussion of everything related to risk prevention, and responses to disasters (CIHSES, 1876). Within the area of rescue, a special section was hosted about relief on the battlefield, along with prevention of, and relief for, other disasters both technological and natural. The unofficial Red Cross meeting dealt with wounded transport and identification of corpses as well as with hygiene responses to issues like management of wandering or wounded animals after the battle, illumination of the battlefield to ease the removal of the wounded and dead, procedures for corpse management (provisional inhumation, cremation, desiccation, confinement in cement, and so on). ${ }^{29}$

However, new developments in relief action in civil disasters (fires, floods, railways crashes, etc.), even in daily life, were being promoted throughout the 1870 s by voluntary aid societies either within the framework of the Red Cross movement or separately though in conjunction with specific Red Cross societies. These developments went on from the earliest establishment of ambulances -in the sense of first-aid dispensaries- in Algeria to the foundation of St John Ambulance in England. The Société des Hospitaliers d'Afrique: comité de secours aux blessés, invalides, veuves, orphelins et étrangers valétudinaires, ${ }^{30} \mathrm{com}$ plemented its promotion of these ambulances from 1872 with short courses for volunteers' training so that "every citizen whose practical knowledge of first aid was considered as sufficient, would be given the armband of the Red Cross securing him an absolute freedom of action and of initiative in case of accidents outdoors" (Bertherand, 1872, p. 20). The St John Ambulance was founded in 1877 as non war-oriented first-aid work dealing with facing small scale and neighbourhood disasters. ${ }^{31}$ In France, the 2e Congrès international d'hygiene -held in Paris on the occasion 
of 1878 Universal Exhibition- made it clear that other relief societies looked on the Red Cross societies as peers, so that they invited them to join forces and work together (CIHSES, 1878). Last but not least, in the United States, the American Red Cross (ARC) was eventually founded in 1881, as a relief society entirely independent from the national army, and focused on civil objectives. ${ }^{32}$

At the time the 1869 Berlin Conference closed, there was no clear response to the question of whether peacetime action of the international association of aid societies should be opened up to new projects, because their delegates had no powers in terms of public health policy, their potential agreements could be not imposed to any country, and the national aid societies could not force individuals or collectives to act in any particular way. The variety of their responses needs to be seen as yet another expression of the emergence of distinct public health views and practices. Thus, around 1880, different national Red Cross societies appear to have given very disparate responses, for instance, in the area of civil disasters, as is obvious from the proceedings of the Third International Conference of Red Cross Societies held in Geneva in 1884 (CIACR, 1884). ${ }^{33}$

While according to the Prussian-led German central committee on that occasion, giving relief to the victims of disasters in peacetime was not, in principle, useful "despite the resolutions of the Berlin international conference", ${ }^{34}$ other German committees such as those of Baden and Bavaria chose to refrain from acting at all, and left their aid societies freedom of action (CIACR, 1884 , pp. 268,184$)$. In contrast, the Red Cross attitude in the Austro-Hungarian Empire appears to have been more inclined to act in the face of civil disasters. Indeed, the Union of Austrian Red Cross societies provided supplies during the 1882 floods in Tirol and Carinthia with the help of the Hungarian aid societies ${ }^{35}$ (CIACR, 1884, p. 293). And three years before, on the occasion of floods in the city of Szeged (1879), the Hungarian societies set up "a big popular kitchen" and distributed 109,102 free meals, in addition to establishing "a day nursery, a kindergarten, a sewing room and a basket workshop" (CIACR, 1884, pp. 327).

On the other hand, the Russian Red Cross society assumed the obligation to fight "public calamities" by giving different kinds of humanitarian relief (money, medical help and the provision of basic necessities on various occasions during the 1870s, namely food in a famine at Samara, house disinfection measures to fight diphtheria in Vetlianka, Poltava, Novdorg, and other places, and money to help different populations after fires, as well as other interventions (CIACR, 1884, pp. 367-369). ${ }^{36}$

Furthermore, the vice-president of the Athens central committee claimed that "inertia and indifference in the face of civil calamities" would be the "most certain path towards lassitude and even the death of Red Cross societies" because these were mostly "national and humanitarian". Indeed, in 1878 the Greek Red Cross had not only given relief to the wounded in the Russian-Turkish war, but also sustained for a year 32,000 refugees displaced as a result of that war, while in subsequent years it would give relief on the occasion of such various "civil calamities" as an earthquake on the island of Chio, a typhus epidemic in Athens, or the evacuation of refugees after the bombing of Alexandria by the British fleet (CIACR, 1884, p. 175).

Last but not least, a delegate from the recently founded American Red Cross (1881) claimed that "the great disasters in peacetime required, equally as in wartime, personnel well trained, experienced and able to work in harmony as well as a large, prompt and organized private charity". He also claimed that the Red Cross was acting in the United States on the clear assumption that "many terrible calamities will hit our people in peacetime" in contrast to the great improbability of a war in the future -a view that might recall that of Virchow in the previous conference at Berlin in 1869. Yet, he insisted that according to the American Red Cross' action plan, its sphere of action in peacetime would be rigorously limited to the "greatest national calamities" (CIACR, 1884, pp. 179-183).

\section{LAST REMARKS}

During the first twenty years of the Red Cross international movement, the action of the distinct relief societies in peacetime went ahead, at a different pace and on different fronts, far beyond its original in pace para bellum. What we have shown here appears to be the opening to, and the mixing of, several processes:

1) Human and material resources were being adapted to humanitarian activities which went beyond the legal technology of the 1864 Geneva Convention, on the basis of a moral interest irrespective of other potential concerns (political, social, economic, cultural,...).

2) Relief activities were becoming part of the mainstream hygiene movement, by understanding prophylaxis as risk prevention, and by moving health care from mere individual rescue in disasters to a continued action on public health and welfare on the basis of increasingly systematic health policies and philanthropic practices.

3) Disasters of natural, technological or human origin were being perceived as equal in their effect, so that they could be dealt with under a common pattern of scientific analysis and prevision in order to eliminate risk factors and to provide aid as promptly and efficiently as possible. 
In 1882 Gustave Moynier -who had been openly opposed, at least since 1865, to the idea that aid societies in their peacetime activities went beyond preparing themselves for wartime (AIPSS, 1865, pp. 514522)- warned about the multiplication of aid societies' interventions to provide relief for the victims of "great public calamities" like famine, epidemics, shipwrecks, fires, earthquakes and other disasters, by warning that these interventions "out of their normal sphere" lacked any "capacity to claim the support of societies of other countries". Furthermore, he qualified the activities as an indisputable abuse, to "hide behind the cover of the legal flag of the Geneva Convention, tasks different to those established by that agreement" (Moynier, 1882, pp. 90-91). Almost four decades had to elapse before the ICRC first stated, soon after the Armistice was signed on 11 Nov 1918, that this was the time for the

\section{NOTES}

1 The proceedings of the Berlin Conference were separately published in German and French. All quotations from these proceedings will refer to the French version: CIACR, 1869, henceforth.

2 In the third edition of his Souvenir of Solferino (February 1863), Dunant had added the footnote as follows: "Ces Sociétés pourraient même rendre de grands services pendant des époques d'epidémies, ou dans des désastres comme des inondations, des incendies; le mobile philanthropique, qui leur aurait donné naissance, les ferait agir dans toutes les occasions où leur action pourrait s'exercer" (Dunant, 1863, p. 152). Later, this note disappeared from both the subsequent editions of the Souvenir, and the republication of its last third part in all the versions of his $L a$ charité dans les champs de bataille.

3 Brinkmann was the author, among other works, of a monograph on voluntary war nurses in Germany with particular attention to their services on the occasion of the Austro-Prussian war of 1866 (Brinkmann, 1867) and of an article on preventive measures against epidemics during wars, which was published in the journal of Prussian aid society of wounded soldiers (Brinkmann, 1870).

4 "Propositions du Comité central prussien" (CIACR, 1869, pp. 1517); "Propositions des autres Comités centraux " (CIACR, 1869, pp. 17-18); "Mémoire concernant l'action des Sociétés de secours aux militaires blessés et malades, en temps de paix" [doc 7] (CIACR, 1869, pp. 27-36); "Action des Sociétés de secours pendant la paix" (CIACR, 1869, pp. 153-208 [4th session], 211215, 251-253 [5th session]).

5 "En temps de paix, les Comités et les Sections s'occupent des moyens de se rendre véritablement utiles en temps de guerre, spécialement en préparant des secours matériels de tout genre, et en cherchant à former et à instruire des infirmiers volontaires." (CIACR, 1869, p. 154).

6 Since 1867 an innovative model of hospital-barrack had been developed as an annex to the Charité Hospital in Berlin by Dr. Esse, director of this hospital. On this and other hospital-barracks, see Demoget (1871). For Dr Esse's model, see pp. 275-282 (illustration on p. 277). whole Red Cross international movement to officially extend its action towards new relief duties in peacetime, in the framework of, first the League of Red Cross Societies (LRCS, established in 1919), and then the International Red Cross (1928) a coordinating body comprising the National Red Cross societies, the ICRC and the LRCS (Durand, 1984, pp. 139-194).

\section{ACKNOWLEDGEMENTS}

This contribution is the result of ongoing research within the framework of a project funded by the Dirección General de Investigación (Spanish Government), "Sanidad militar, medicina de guerra y humanitarismo en la España del siglo XIX" (HAR2011-24134). A first approach was presented in the EAHMH Conference "Risk and disaster in medicine and health" (Lisbon, 4-7 Sep 2013).

7 For overviews on public health and industrialisation in France and Germany, the main actors at the Berlin Conference, see Rosen (1993, pp. 226-235) y Porter (1999, pp. 99-109).

8 "Dans cette classe nous trouvons, en général, sous tous les rapports, l'idéal des infirmiers et des infirmières et les qualités indispensables aux garde-malades, le dévouement parfait au devoir, avec abnégation complète de soi-même, la renonciation à toutes les habitudes et à toutes les aises de la vie, et avec tout cela une amabilité joyeuse en toute occupation, la sérénité d'âme à la vue de tout spectacle si terrible qu'il soit, enfin la soumission et l'obéissance absolues"' (CIACR, 1869, p. 30).

9 (CIACR, 1869, pp. 30-31, 156-157). Behind this prudent defense of nursing as a suitable profession for trained women without religious vocation is the fact that the care of patients by non religious nurses was then a controversial issue particularly, although by no means exclusively, among conservative Catholics. On the complexities of hospital nursing across the confessional divide in nineteenth-century Germany, see Nelson (2001, pp. 126-150).

10 (CIACR, 1869, p. 31). The reluctance of the Prussian government and army to allow civil males on the battlefield was by no means unconnected to this prohibition.

11 (CIACR, 1869, p. 1663). One year after the Berlin Conference, Schmidt published a brief historical approach to the development of "hospital system" and nursing (Schmidt, 1870). In October 1871 he actively participated in the first meeting of German aid societies held at Nuremberg (DRK, 1871, pp. 78, 136, 153). Finally, in 1874 , he published a modification proposal to the Geneva Convention and of the 1868 agreements for its extension, in order to transform them into laws of war (SchmidtErnsthausen, 1874).

12 Schmidt's observations on the impact of this urban overpopulation on the traditional hospital system are remarkable: "La proportion ascendante des malades par suite des conditions hygiéniques insuffisantes des ateliers, des habitations, etc., réagit d'une manière désastreuse sur le régime des hôpitaux et en rend partout l'agrandissement nécessaire. Mais cet agrandissement 
rencontré presque partout aussi des obstacles, faute de place ou pour des raisons hygiéniques, ainsi qu'en ont fait l'expérience la plupart des hôpitaux qui, par suite de l'extension des villes, ont fini par se trouver au centre, tandis qu'auparavant ils se trouvaient placés à l'extérieur" (CIACR, Berlin, 1869, p. 166).

13 For a comparative approach to the urban sanitary movement in England and in Germany, see Hennock (2000).

14 On health care and poor relief in Germany during this period, see Sachsse \& Tennstedt (1980, pp. 179-331, 346-367); Tennstedt (1981, pp. 78-134). On the specific case of Prussia, see Dross, 2002; on that of Bavaria, see Stolberg (2002).

15 On the medical reform of US and Scottish hospitals at the time, see Risse (1999, pp 361-398); and Rosenberg, (1987), respectively. On the new tendencies in hospital building, see Demoget (1871) y Bosc (1876).

16 These were the propositions no. 20 and 21 in the summary of the Conference's results (CIACR, 1869, pp. 203, 253). They corresponded to propositions no. 1 and 7 in the Prussian initial proposal (CIACR, 1869, pp. 15-16, 29).

17 (CIACR, 1869, pp. 177-179). The difficulties posed by the Austrian committees due to the strong involvement of the chivalric orders can be more easily understood after a further intervention of another Austrian delegate, the Count of Lichnowsky, who was representative of the Order of Malta (CIACR, 1869, p. 192).

18 Von Hübbenet (1822-1873) wrote, among other works, a monograph on the sanitary conditions of the Russian soldiers wounded in the Crimean War (Von Hübbenet, 1871).

19 (CIACR, 1869, pp 181-184). On the growing concern about relieving accident victims all over Europe during the four decades after the Franco-Prussian war, see Hutchinson (1997). On the French case, see Hutchinson (1997), pp. 163-166.

20 (CIACR, 1869, pp. 195-196). On Rudolf Virchow, see Ackerknecht (1953); Pruell (2010).

21 “... il est à désirer que l'activité volontaire reste libre, afin que le succès ne soit pas trop toujours composé d'une manière convenable pour le but qu'on se propose" (CIACR, 1869, p. 196).

22 In the middle of the Franco-Prussian war, Virchow persisted in claiming that it was crazy to prepare themselves for war as if it were the natural state of Europe. See Virchow (1870).

23 On Rudolf Virchow's reformist concerns in public health, and his involvement in the 1848 liberal revolution and other political activities, see Ackerknecht (1953, pp. 123-145, 159-191).

24 This speech by Virchow and the briefer one, already mentioned, reported on pp. 195-195, were reproduced in German along with his final commentary in Virchow (1879), pp. 110-114.

25 (CIACR, 1869, pp. 205-207). The public hygiene issues raised by Weber on this occasion were by no means new. In fact, they had been already debated in the $1^{\text {st }}$ Congress of public hygiene held at Brussels in 1851. Although no official proceedings were then published, the debates can be followed in Annales d'hygiène publique, industrielle et sociale, vols. 47, 48 and 49 (CGHP, henceforth).
26 (CIACR, 1869, p. 190). Brinkmann's allusion here to a "humanitarian society" was related to the fact that Buchner had attributed to him the promotion of the idea of setting up a "General Association of Humanity" -an idea circulating in some writings on aid societies' action that Buchner found to be a dangerous exaggeration. Brinkmann took advantage of his reply to stress that he had found a crucial difference between Virchow's position and that of Buchner, for whereas the latter had "restricted" the activity of aid societies in peacetime, the former had extended it. Then, Buchner excused himself by admitting having only read about the idea of a "Universal Humanitarian Association" in a recently published work not written by Brinkmann, and by arguing that his aim was just to "alert against the dispersion of our activity, against the volatility ... resulting from an excessive generalisation of the work [i.e., the Red Cross]" (CIACR, 1869, pp. 162, 207).

27 Gilli served as a sculptor in marble, designer of murals, and restorer of antiques at the court of Prince Karl of Prussia, Grand Master of the Order of Saint John.

28 Berliner physician of Jewish family who was very active in making proposals of reform in health care and welfare.

29 For "relief in wartime" (Secours en temps de guerre), see CIHSES (1876, vol. II, pp. 179-413).

30 Founded in Alger in 1871, and presided by the physician and publicist Émile Bertherand (1821-1890), the Société des Hospitaliers d'Afrique operated since its very beginning in coordination with the Société des Sauveteurs d'Alger for maritime disasters. Moynier echoed the former Société, though emphasising its activities concerning relief of war widows, orphans, and wounded, and only marginally referring to its civil relief ones (See, Bulletin International des sociétés de secours aux blessés 4 (1872) 13, pp. 21, 25-26)

31 On the British case, see, e.g., Cooter (1997) and Gill (2013) -in addition to Gill's article in this publication.

32 On the history of the ARC see, e.g., Jones (2013).

33 The fifth point at that conference was devoted to the role of the Red Cross in non-wartime disasters: "La Croix-Rouge dans les calamités publiques autres que la guerre” (CIACR, 1884, pp. 174-185).

34 “Fidele au principe consacré par l'expérience, que la concurrence, quelque utile et avantageuse qu'elle soit pour d'autres choses, ne doit pas être considérée comme désirable quand il s'agit d'efforts humanitaires et que, sur ce terrain, un travail unifié et des forces combinées sont préférables à une activité partielle et divisée, quelque grande qu'on la suppose, .... le Comité central allemand n'a pas trouvé utile de s'occuper à adoucir le sort des victimes dans les calamités publiques en temps de paix, malgré les résolutions de la Conférence internationale de Berlin" (CIACR,1884, pp. 260-261).

35 After the defeat of 1866 by Prussia, the Austrian Empire became the Austro-Hungarian Empire, each country with its own institutions.

36 “... les secours ne consistaient pas toujours en offrandes pécuniaires, mais souvent en objets dont les malheureux avaient un besoin pressant, soit pour le secours médical, soit pour les nécessités quotidiennes de la vie. En conséquence, dans certains cas, on envoyait un personnel médical avec tout le nécessaire, ainsi que des habillements et des aliments, dans d'autres, le secours se bornait à la distribution d'effets et d'argent" (CR-CIAC, 1884, p. 368). 


\section{BIBLIOGRAPHY}

Ackerknecht, Edwin H. (1953), Rudolf Virchow: doctor, statesman, anthropologist. Madison, WIS, University of Wisconsin Press.

[AIPSS, 1864], Annales de l'Association internationale pour le progrès des sciences sociales: Troisième session. Congrès d'Amsterdam (1865), Brussels, Bols-Wittouck / Paris, Guillaumin et Cie.

[AIPSS, 1865], Annales de l'Association internationale pour le progrès des sciences sociales: Quatrième session (du 28 août au 2 septembre 1865): Congrès de Berne (1866), Brussels, Bols-Wittouck / Paris, Guillaumin \& Cie.

Beaufort, François L. C. A. d'Hertault, Comte de (1870), Étude sur la Société française de secours aux blessés des armées de terre et de mer et sur la Convention de Genève, Pris, Paul duPont.

Beaufort, François. L. C. A. d'Hertault, Comte de (1875), Questions philanthropiques. Transport de blessés, hôpitaux, appareils, assistance aux mutilés pauvres, etc., Paris, Imprimerie Nationale.

Bertherand, Émile (1872), “Compte rendu des opérations de l'exercice 1871-1872", Bulletin de la Société des Hospitaliers d'Áfrique, 1 (1), pp. 5-26.

Boissier, Pierre (1985), History of the International Committee of the Red Cross. From Solferino to Tsushima, Geneva, Henry Dunant Institute.

Bosc, Ernest (1871), Étude sur les hôpitaux et les ambulances, Paris, Ve. A. Morell \& Cie.

Brinkmann, Wilhem (1867), Die Freiwillige Krankenpflege im Kriege. Mit besonderer berücksichtigung ihrer leistungen im Jahre 1866, Berlin, Enslich.

Brinkmann, Wilhem (1870), "Über vorsorgliche Massregeln zur Verhütung von Epidemieen im Kriege”, Kriegerheil, 1, pp. 137-144.

De Cazenove, Léonce (1869), La guerre et l'humanité au XIXe siècle, París, Arnaud de Vresse.

Cooter, Roger (1997), "The moment of the accident: culture, militarism and modernity in late-Victorian Britain", in Roger Cooter \& Bill Luckin (eds.), Accidents in history: injuries, fatalities and social relations, Amsterdam-Atlanta, Rodopi, pp. 107-157.

[CGHP, 1851], “Compte rendu de Congrès Général d'Hygiene Publique de Bruxelles, session de 1852" (1852-1853), Annales d'hygiene publique et de médecine legale (Paris), 48: 443-476; 49, 204-245.

[CIACR, 1869], Compte rendu des travaux de la Conférence Internationale tenue à Berlin du 22 au 27 avril 1869 par les délégués des governements signataires de la Convention de Genève et des Sociétés et Associations de secours aux militaires blessés et malades (1869), Berlin, Imprimerie J.F. Starcke.

[CIACR, 1884], Troisième Conférence Internationale des Sociétés de la Croix-Rouge teune à Genève du 1er au 6 septembre 1884 (1885), Geneva, CICR.

[CIHSES, 1876], [1st] Congrès international d'hygiène, de sauvetage et d'économie sociale (Bruxelles, 1876) (1877), Paris, Germer
Baillière; Bruxelles, Veuve Henri Manceaux, 2 vols: vol. I (Hygiène); vol. II (Sauvetage - Économie sociale).

[CIHSES, 1878], [2nd] Congrés international d'Hygiene, tenu à Paris du 1 er au 10 aout 1878 (no. 10 at the series Comptes rendus sténographiques des congrès et conferences de palais du trocadéro de la Exposition Universelle) (1880), Paris, Imprimerie Nationale, 2 vols.

Demoget, A. (1871), Étude sur la construction des ambulances temporaires suivie d'un essai sur l'application des baraquements a la construction des hôpitaux civils permaments, Paris, Alf. Cerf, éditeur.

[DRK, 1871], Verhandlungen des ersten Vereins-Tages der Deutschen Vereine zur Pflege im Felde verwundeter und erkrankter Krieger und der Deutschen Frauen-Vereine (1871), Berlin, Julius Sittenfeld.

Dross, Fritz (2002), "Health care provision and poor relief in Enlightenment and $19^{\text {th }}$ century Prussia", in Ole Peter Grell, Andrew Cunningham and Robert Jütte (eds.), Health care and poor relief in $18^{\text {th }}$ and $19^{\text {th }}$ century Northern Europe, Aldershot, Ashgate, pp. 69-111.

Dunant, J. Henry (1863), Un souvenir de Solférino, $3^{\text {rd }}$ ed., Genève, Jules-Guillaume Fick.

Durand, André (1984), History of the International Committee of the Red Cross. From Sarajevo to Hiroshima, Geneva, Henry Dunant Institute.

Gill, Rebecca (2013), Calculating Compassion: Humanity and Relief in War, Britain 1870-1914, Manchester, Manchester University Press.

Hennock, E.P. (2000), "The urban sanitary movement in England and Germany, 1838-1914, a comparison", Continuity and Change, 15(2), pp. 269-296.

Von Hübbenet, Anton Christian August (1871), Die Sanitäts-Verhältnisse der Russischen Verwundeten während des Krimkrieges in den Jahren 1854-1856, Berlin, A. Hirschwald.

Hutchinson, John (1996), Champions of charity. War and the rise of the Red Cross, Boulder (Co), WestViewPress.

Hutchinson, John (1997), “Civilian ambulances and lifesaving societies: the European experience, 1870-1914", in Roger Cooter \& Bill Luckin (eds.), Accidents in history: injuries, fatalities and social relations, Amsterdam-Atlanta, Rodopi, pp. 158-178.

Hutchinson, John (2000), "Disasters and the International Order: Earthquakes, Humanitarians, and the Ciraolo Project", The International History Review, 22 (1), pp. 1-36.

Jones, Marian Moser (2013), The American Red Cross from Clara Barton to the New Deal, Baltimore, The Johns Hopkins University Press.

Longmore, Thomas (1872), “On the Geneva Convention of 1864, in relation to the aid afforded by volunteer societies to sick and wounded soldiers during the Late Franco-German War, with a glance at the proper functions of National Aid-Societies, particularly the British Aid-Society, in the future", Journal of the Royal United Service Institution, 16(2), pp. 206-221. 
Moynier, Gustave (1882), La Croix-Rouge : son passé et son avenir, Paris, Sandoz et Thullier.

Nelson, Sioban (2001), Say little, do much: nurses, nuns, and hospitals in the nineteenth century, Philadelphia, University of Pennsylvania Press.

Pitteloud, Jean-François (ed.) (1999), Procès-verbaux des séances du Comité international de la Croix-Rouge 17 février 1863 - 28 août 1914, Geneva, Société Henry Dunant - Comité International de la Croix-Rouge.

Porter, Dorothy (1999), Health, civilization and the state. A history of public health from ancient to mdern times, London Routledge.

Pruell, Cay-Ruediger (2010), "Virchow, Rudolf Karl", in W.F. Bynum \& Helen Bynum, Dictionary of medical biography, Westport, CTLondon, Greenwood Press, pp. 1272-1277.

Rosen, George (1993), A history of public health [1958], $2^{\text {nd }}$ ed., Baltimore, The Johns Hopkins University Press.

Sachsse, Christoph; Tennstedt, Florian (1980), Geschichte der Armenfürsorge in Deutschland: Vom Spátmittelalter bis zu 1.Weltkrieg, Stuttgart, W. Kohlhammer.

Schmidt-Ernsthausen, Maximilian (1870), Allgemeine Umrisse der culturgeschichtlichen Entwicklung des Hospitalwesens und der Krankenpflege, Gotha, E. F. Thienemann.
Schmidt-Ernsthausen, Maximilian (1874), Das Princip der Genfer Convention vom 22. August 1864 und der freiwilligen nationalen Hülfsorganisation für den Krieg: Studie, Berlin, Mittler.

Stolberg, Michael (2002), "Health care provision and poor relief in the Electorate and Kingdom of Bavaria", in Ole Peter Grell, Andrew Cunnnigham and Robert Jütte (eds.), Health care and poor relief in $18^{\text {th }}$ and $19^{\text {th }}$ century Northern Europe, Aldershot, Ashgate, pp. 112-135.

Sudahl, Alexander (2001), Das Rote Kreuz im Königreich Württemberg, Heildelberg, Ruprecht-Karls-Universität (Institut für Geschichte der Medizin. Ph D Thesis), [online] avalaible at http:// www.ub.uni-heidelberg.de/archiv/3029 (20 Jan 2014)

Tennstedt, Florian (1981), Socialgeschichte der Sozialpolitik in Deutschland, Göttingen, Vanderhoeck-Reihe.

Virchow, Rudolf Ludwig Karl (1870), “Der Krieg und die Wissenschaft", Archiv für pathologische Anatomie und Physiologie und für klinische Medizin, 51(1), 22 Sept, pp. 4-8. [English version (1870): "Professor Virchow On the war", The Medical Times and Gazette, 2, 22 Oct, pp. 484-485].

Virchow, Rudolf Ludwig Karl (1879), Gesammelte Abhandlungen aus dem Gebiete der öffentlichen Medizin und der Seuchenlehre, Berlin, A. Hirschwald, 2 vols. 